\title{
THE EXISTENCE AND ROLE OF LEGAL HIGHER EDUCATION IN LAW ENFORCEMENT DURING THE COVID-19 PANDEMIC IN INDONESIA
}

\author{
Moch Thariq Shadiqin, Ummi A'zizah Zahroh \\ Diponegoro University, Sebelas Maret University \\ mochthariqshadiqin@students.undip.ac.id \\ ummiazzahroh@student.uns.ac.id
}

\begin{abstract}
The Covid-19 pandemic has made learning in Higher Education carried out at home. This is a challenge in itself for the Higher Education Law, how it can still produce excellent and professional law enforcement human resources even though they are limited. This article aims to see Law Higher Education try to continue to show its existence and role. The type of research in this article is normative juridical law research. The data collection method used in writing scientific papers is carried out using library research, namely by searching for legal materials and social data relevant to the subject matter, which is the study in writing this scientific paper. Law Higher Education made a breakthrough in the form of learning through Microsoft Teams and Zoom applications. Not only that, this official institution tries to continue to hold activities outside of lectures, such as workshops, webinars using the Youtube channel. It's to continue to produce professional law graduates. However, it is undeniable that there are still several obstacles, including mastery of technology, the risk of casualties, and the opportunity to study practical work, which can only be done in student domiciles.
\end{abstract}

Keywords: Legal Higher Education; Existence; Covid 19

Received 30 January 2021 Accepted 31 January 2022

\section{INTRODUCTION}

Making an uproar, World Health Organization (WHO) has announced a global covid-19 pandemic since March 11. Worldwide infections have reached over 121,000.[1] This affects people's activities in everyday life. One of the above impacts is a decrease in human activity due to lockdown policies in several countries. The Indonesian state did not carry out a lockdown. Still, it carried out Large-Scale Social Restrictions (PSBB), which was marked by the issuance of the 2020 Government Regulation, which impacted various sectors. Starting from the agricultural industry in second place to the air transportation sector in the first rank.[2] However, what is no less important is the sector education. UNESCO site until March 31 stated that 61 countries in Africa, Asia, Middle East Europe, and South America have implemented learning restrictions in schools and at universities. Nearly 421 million children and adolescents in the world are affected.[3] In Indonesia itself Higher Education has learned from home since last March 2020. This was later confirmed by the Minister Education and Culture, Nadiem Makarim that method This learning will continue to be carried out in the following academic year starting August 2020.[4].

The decision above is, of course, the Higher Education making a super-fast revolution in digitization. Initially learning remotely or at home, this is only an emergency solution at first 
March when home studies begin. However, it is now inevitably becoming the primary system that can be relied on to keep the learning system running at the university level High. The Law College is one of the institutions that finally participate in following the policy. Whereas the best tool for public policy as an effort to improve skills and knowledge is the learning process on campus/ school.[5]

During the Covid-19 pandemic, learning in Higher Education was carried out in their respective homes. This is undoubtedly a challenge in itself for the Higher Education of Law, how it can still produce excellent and professional law enforcement human resources even though they are limited. The existence of a higher education law seems to be questioned about its role. Given that there is still a lot of homework in the field of law enforcement in Indonesia.

Naturally, if a Law College is a target because the public in assessing a law college's success is how to create a professional law enforcer. The indicator is how many levels of law graduates have violated the law. The low level of success of law colleges in producing law graduates or professional law enforcers is shown by law graduates' high level of law violations. On the other hand, law colleges' high success in creating professional law enforcers is demonstrated by the low level of law violations committed by law graduates and/or law enforcers.

From the description above, the formulation of the problem can be drawn as follows: (1) How is the Existence of Legal Higher Education in Law Enforcement During the Covid-19 Pandemic? (2) What are the obstacles faced and what are the solutions?

\section{LITERATURE REVIEW}

\section{Large-Scale Social Restrictions (PSBB)}

A Large-Scale Social Restriction is an effort to spread certain activities of residents in an area suspected of being infected with Covid-19 to prevent the possible spread of Coronavirus (Covid-19). [6]

In its implementation, several other conditions must be :

a. The number of cases and/or the number of deaths due to the disease has increased and spread significantly and rapidly to several regions; and;

b. Occur in epidemiological areas with similar incidence or other countries

Forms of enactment of large-scale social groups include school and work vacations, religious activities, and/or; activities in public places and facilities.[7]

\section{Higher Education of Law}

Higher education is the education level after education intermediate education programs, including diploma, bachelor, master, specialists, and doctors organized by universities.[8] Higher education is the final foundation for all levels of education and as a vehicle for the formation of scholars who have a noble character, carry out cultural values, advance life, and formed a pinandita warrior.[9]

Sudikno Mertokusumo argued that law as a collection of regulations or rules in everyday life or the fundamental rules of behavior in life together are coercive, and there is a sanction. Law is defined as a collection of regulations or rules with general and normative content, generally defined as everyone, and normative determines what can be done and what cannot be done.[10]

The previous description concludes that legal higher education is an educational program that studies regulations or rules in life together. The fundamental laws of behavior that exist in coexistence are coercive and there are sanctions for those who violate. 


\section{RESEARCH METHOD(S)}

The type of research in this article is normative juridical law research. Normative juridical writing or normative legal research is literature research, namely research on secondary data.[11] In this study, an assessment of legal principles against legal norms is carried out which are benchmarks for behavior.[12] This legal research uses an approach commonly used in legal research (Legal Research), including: a statutory approach (Statute Approach), and a conceptual approach (Conceptual Approach).

The data collection method used in writing scientific papers is carried out by means of library research, namely by searching for legal materials and social data that have relevance to the subject matter which is the study in writing this scientific paper.[13] The collected data is then processed by systematizing written legal materials. Systematics means making classifications of these legal materials to facilitate analysis and construction work. Data collection methods include activities to search for data through reliable sources on the internet, as well as comprehensive review of laws and policies.

\section{FINDINGS AND DISCUSSION}

\section{The Existence and Role of Legal Higher Education in Law Enforcement During the Covid-19 Pandemic}

The existence of professional law enforcement officers is inseparable from the role and existence of law colleges. This is because law colleges are official institutions that produce law graduates. Although many law universities have spread in Indonesia, this is a question mark whether Faculty of Law graduates have a positive role in law enforcement or not. With Indonesia's legal conditions that have not changed much from a sad situation, it is not wrong to ask questions about how the existence and role of higher education in law exists.

The irony is that there are many law violations committed by law graduates themselves. Call the case of Attorney Pinangki recently in Djoko Tjandra, who was caught in a corruption case. Attorney Pinangki was charged with receiving US \$ 500,000 from Djoko Tjandra, and many other law enforcement officers in violation of the law.

Legal Higher Education as an official institution that produces law graduates should be held accountable for the graduates who are born. In addition to the problems above, if we see that several law enforcement institutions in the selection process for law enforcement candidates require special education for certain professions such as Judge Candidate Education, Advocate Professional Special Education or commonly abbreviated PKPA.

Although the material presented is more of a technical nature, such as proficiency in writing correspondence for trial needs, legal argumentation (legal reasoning), code of ethics, and so on. However, the methods and materials presented do not appear to be much different from the ordinary course materials in higher education such as procedural law and a small part of material law. However, the methods and materials presented do not appear to be much different from the ordinary course materials in higher education such as procedural law and a small part of material law. However, the education of candidates for Judges and Prosecutors has gone deeper into practical technicalities.[14] his is undoubtedly a challenge for Higher Education in Law to make breakthroughs to be done and maximized during lecture activities.

When graduated, a law degree when graduating must be ready to go into society to solve existing problems. This is the role of higher law education in producing competent human resources, especially in law enforcement. Mochtar Kusumaatmadja further argues that a wellplanned clinical education teaches technical skills and situations that are encountered in the community later and must add a habit or problem-solving attitude.

The homework of the Law Higher Education has not been completed in an effort to produce competent, integrity, and professional law enforcers, now the Covid-19 Pandemic is sweeping the entire world, including Indonesia. Student learning is interrupted. This institution 
is required to continue to show its existence and role during the pandemic. Various efforts have also been made, such as learning through Microsoft Teams and even zooming. But what is no less interesting is holding webinars, workshops, and even learning breakthroughs using the YouTube channel.

One of them is the Higher Education Law, which is actively holding webinars is the Faculty of Law, Diponegoro University. Recently had a webinar with the theme "The Existence and Problems of Corporate Criminal Liability in Indonesia."[15]

Reporting from the official website of the Faculty of Law UNDIP. Head of the UNDIP Master of Law Study Program, Dr. Joko Setiyono, S.H., M.Hum. in his speech explained:

"Target in this webinar is that the webinar participants are expected to gain legal knowledge and be able to understand and think objectively regarding corporate criminal liability, and the webinar participants are expected to be able to analyze related corporate criminal liability."

This is undoubtedly a breakthrough solution during the Pandemic for Legal Higher Education to continue to show its existence and role. Webinars that can be attended by the general public indicate that legal knowledge can be accessed by the wider community, not only candidates for bachelor's and master's degrees in law but the general public. This means that the general public's knowledge of the law increases even more literate towards the direction. Including law, enforcers can improve their understanding through this webinar.

\section{Constraints faced and how to solve the solution}

\section{a. Technology}

During the Covid-19 pandemic, lecturers were required to conduct lectures according to the curriculum set before the pandemic. However, the implementation is different. Lecturers are required to operate various supporting applications such as Zoom, Google Classroom Group, Whatsapp, and other applications. Of course, this is something new for lecturers. With limited face-to-face time and considering the use of quotas for students, lecturers are still required to deliver material comprehensively as in normal conditions before Covid-19.

Even though some courses in Higher Education of Law require direct practice so that they are easy to understand, such as the Judicial Practice / Litigation Skills course, quoted from the Semester Learning Design (RPS) for Civil Procedural Law and Civil Justice Practices, Hasanuddin University, Faculty of Law, Undergraduate Program, one of the indicators of learning objectives states that "Students are able to practice the civil procedure process."[16]

Although some subjects can be tricked using technology. However, in lectures, some obstacles are prevalent when using an internet connection, namely the inadequate telecommunications network in every student area. As a middle way, lecturers switch to the assignment method when learning online. [17]

\section{b. Victim Risk}

As long as higher education conducts lecturing activities remotely does not mean it does not have risks. It was reported that there was a victim who died after a traffic accident while searching for the location of the internet network for online lectures, namely a student of Muhammadiyah University (Unismuh) Makassar majoring in PGSD.[18] Not only one victim of the same incident was also experienced by Hasanudin Makassar students. While trying to find an internet network to do his job, he fell from the mosque's minaret.

Even though there are no victims in the Legal Higher Education environment, this does not mean that online lectures can be said to be one hundred percent safe. 
Moreover, almost all higher education applies the same learning method, namely relying on the internet network, which means that each line of higher education has the same risk.

\section{c. Job Training Opportunities}

It is undeniable that the theory that has been obtained at the College of Law without being accompanied by field practice is deemed incomplete. This is because the world of work requires people who not only graduate with good academic grades, but they need communication skills, integrity, and the ability to work with others.[19]

Usually, students of the Faculty of Law do practical work in various regions in Indonesia such as the Ministry, Law Firm, Attorney General's Office, Courts, Judicial Commission, or even companies that have a legal division. However, it is unfortunate because of the policy to study online and some regional restrictions that have been done, this has indirectly limited the opportunities for students to choose a place for practical work.

However, the existence of the Covid-19 Pandemic does not mean that Legal Higher Education cannot fully carry out this agenda. Job Training can still be carried out but in the student's domicile. As what was done by Padang State University (UNP) in August. Reporting from Antaranews.com, Prof. Ganefri, Ph.D. as the chancellor of UNP said:[20]

"This year's field practice will be carried out on a residence-based basis while still considering referring to the conditions of the school which must meet the requirements, especially in terms of accreditation from the school being the place and partner of UNP"

Although UNP does not have a Law Faculty, this does not mean that this method cannot be applied in Higher Education Law. Considering the District and High Courts are scattered throughout Indonesia. This does not reduce students' opportunity to get soft skills, especially in law enforcement, even though the Covid-19 pandemic constrains them.

\section{CONCLUSION}

The Role of Law Higher Education is responsible as the creator of Human Resources (HR) of professional law enforcers. During the Covid-19 Pandemic, this Official Institution was required to continue to show its existence despite its limitations. Various efforts have also been made, such as learning through Microsoft Teams and even zooming. But what is no less attractive is holding webinars, workshops, and even learning breakthroughs using the YouTube channel.

The obstacles experienced by the Legal Higher Education in demonstrating their existence and role during the Covid-19 pandemic were of various kinds. They are starting from the limited use of technology, the risk of causing casualties, to the accuracy of practical work courses that are only limited to each student's domicile.

\section{REFERENCES}

[1] World Health Organization. WHO Director-General's opening remarks at the media briefing on COVID-19 2020. https://www.who.int/dg/speeches/detail/who-directorgeneral-s-opening-remarks-at-the-media-briefing-on-covid (accessed March 11, 2020).

[2] Hartomo G. 3 Sektor yang Paling Terdampak Virus Corona. OkyzoneCom 2020. https://economy.okezone.com/read/2020/06/01/320/2222923/3-sektor-yang-palingterdampak-virus-corona (accessed September 2, 2020).

[3] Rizal Setyo Nugroho. Corona: 421 Juta Pelajar di 39 Negara Belajar di Rumah, 
Kampus di Indonesia Kuliah Online. KompasCom 2020.

https://www.kompas.com/tren/read/2020/03/14/120000765/corona-421-juta-pelajar-di39-negara-belajar-di-rumah-kampus-di-indonesia?page=all.

[4] Ananda Teresia. Nadiem: Universitas Masih Belajar Daring, Belum Tatap Muka.

KumparanCom 2020. https://kumparan.com/kumparannews/nadiem-universitas-masihbelajar-daring-belum-tatap-muka-1tcLWHC0RJm/full (accessed September 2, 2020).

[5] Caroline Hodges Persel. Educations and Inequality, The Roots and Results of Strattification in America's Schools. United States of America: The Free Press; 1979.

[6] Minister of Health of the Republic of Indonesia. Regulation of the Minister of Health of the Republic of Indonesia No. 9 of 2020, Article 1. 2020.

[7] Jannah NR. Tinjauan Yuridis Peraturan Pemerintah Nomor 21 Tahun 2020 Tentang Pembatasan Sosial Berskala Besar. Universitas Muhammadiyah Mataram, 2020.

[8] Law Number 20 About the National Education System, 2003. 2003 n.d.

[9] Harsono. Model-Model Pengelolaan Perguaran Tinggi. Yogyakarta: Pustaka Belajar; 2008.

[10] Mertokusumo S. Mengenal Suatu Hukum pengantar. Yogyakarta: Liberty; 1999.

[11] Soemitro RH. Metodologi Penelitian Hukum dan Jurimetri. Jakarta: Ghalia Indonesia; 1998.

[12] Marzuki PM. Penelitian Hukum. Jakarta: Prenada Media Grup; 2005.

[13] Soerjono Soekamto \& Sri Mamudji. Penelitian Hukum Normatif (Suatu Tinjauan Hukum). Jakarta: Rajawali Press; 2001.

[14] Syaifuddin. Reorientasi Kebijakan Pendidikan Tinggi Hukum Dalam Upaya Membentuk Penegak Hukum Professional. Al-Imarah : Jurnal Pemerintahan Dan Politik Islam 2018;3:156.

[15] Moch Thariq Shadiqin. Prodi Magister Ilmu Hukum Universitas Diponegoro Gelar Webinar. Fakultas Hukum Universitas Diponegoro 2020. https://fh.undip.ac.id/prodimagister-ilmu-hukum-universitas-diponegoro-gelar-webinar-bertema-eksistensi-danproblem-pertanggungjawaban-pidana-korporasi-di-indonesia/ (accessed September 3, 2020).

[16] Dr. H. Mustafa Bola, S.H. MH. Rancangan Pembelajaran Semester (RPS). Makassar: Universitas Hasannuddin; n.d.

[17] Abdul BK. Pendidikan Perguruan Tinggi Era 4.0 Dalam Pandemi Covid-19 (Refleksi Sosiologis). Education and Learning Journal 2020;1:109.

[18] Himawan. Seorang Mahasiswi Tewas Saat Cari Sinyal Internet untuk Kuliah Online. KompasCom 2020. https://makassar.kompas.com/read/2020/04/08/19493391/seorangmahasiswi-tewas-saat-cari-sinyal-internet-untuk-kuliah-online (accessed September 3, 2020).

[19] Chandra Suharyanti, Wiedy Murtini TS. Pengaruh Proses Pembelajaran dan Program Kerja Praktek Terhadap Pengembangan Soft Skills Mahasiswa. Jurnal Pendidikan Administrasi Perkantoran 2015;4:2.

[20] Mutiara Ramadhani. Dampak pandemi COVID-19 UNP terapkan sistem praktek lapangan di domisili masing-masing. AntaranewsCom 2020.

https://sumbar.antaranews.com/berita/379966/dampak-pandemi-covid-19-unpterapkan-sistem-praktek-lapangan-di-domisili-masing-masing (accessed September 3, 2020). 